\title{
Bax Involvement in p53-Mediated Neuronal Cell Death
}

\author{
Hong Xiang, ${ }^{1}$ Yoshito Kinoshita, ${ }^{1}$ C. Michael Knudson, ${ }^{2}$ Stanley J. Korsmeyer, ${ }^{2}$ Philip A. Schwartzkroin, ${ }^{1}$ and \\ Richard S. Morrison 1 \\ ${ }^{1}$ Department of Neurological Surgery, University of Washington School of Medicine, Seattle, Washington 98195-6470, \\ and 2 Howard Hughes Medical Institute, Department of Medicine and Pathology, Washington University School of \\ Medicine, St. Louis, Missouri 63110
}

\begin{abstract}
The tumor suppressor gene $\mathrm{p} 53$ has been implicated in the loss of neuronal viability, but the signaling events associated with p53-mediated cell death in cortical and hippocampal neurons are not understood. Previous work has shown that adenovirusmediated delivery of the p53 gene causes cortical and hippocampal neuronal cell death with some features typical of apoptosis. In the present study we determined whether p53initiated changes in neuronal viability were dependent on members of the Bcl-2 family of cell death regulators. Primary cultures of cortical neurons were derived from animals containing Bax $(+/+$ and $+/-)$ or those deficient in Bax $(-/-)$. Cell damage was assessed by direct cell counting and by measurements of MTT activity. Neurons containing at least one copy of the Bax gene were damaged severely by exposure to excito-
\end{abstract}

toxins or by the induction of DNA damage. In contrast, Baxdeficient neurons $(-/-)$ exhibited significant protection from both types of injury. Bax protein expression was elevated significantly by glutamate exposure, but not by camptothecininduced DNA damage in wild-type neurons. The glutamateinduced increase in Bax protein was dependent on the presence of the p53 gene. However, increased p53 expression, using adenovirus-mediated transduction, was not sufficient by itself to elevate Bax protein levels. These results demonstrate that Bax is required for neuronal cell death in response to some forms of cytotoxic injury and further support the key role for p53 activation in response to excitotoxic and genotoxic injury.

Key words: Bax; p53; cortical neurons; apoptosis; glutamate; kainate; camptothecin; neuronal cell death
Cell death - often in the form of apoptosis-is recognized as an essential physiological activity necessary for normal embryonic development (Knudson et al., 1995; Motoyama et al., 1995; Kuida et al., 1996) and tissue homeostasis (Thompson, 1995; Nicholson, 1996). Disruption of the genes that control apoptosis may impair these processes, leading to abnormal tissue development, initiation of tumor progression, and cellular degeneration (Thompson, 1995; Nicholson, 1996). Consistent with this notion, apoptoticlike cell death has been described in association with various human neurodegenerative disorders such as amyotrophic lateral sclerosis (ALS), Parkinson's, Alzheimer's, and Huntington's diseases (Raff et al., 1993; Su et al., 1994; Yoshiyama et al., 1994; Portera-Cailliau et al., 1995; Smale et al., 1995; Thomas et al., 1995; Troost et al., 1995).

Among the mediators of cell death the p53 tumor suppressor gene may have particular relevance in the CNS, where several diverse forms of neuronal damage have been associated with p53 induction (Chopp et al., 1992; Li et al., 1994; Sakhi et al., 1994). The absence of p53 has been shown to reduce neuronal cell

Received Sept. 8, 1997; revised Oct. 27, 1997; accepted Nov. 21, 1997.

This work was supported in part by Grants from the American Cancer Society CB-128, Royalty Research Foundation at the University of Washington, and the Washington Research Foundation to R.S.M.; by National Institutes of Health NS31775 to R.S.M. and NS18895 to P.A.S.; and by National Institutes of Health DK47754 in support of the virology core facility at the University of Washington. This work was performed while C.M.K. was a Pfizer postdoctoral fellow. We gratefully acknowledge Dr. Mark Kay for his help with adenovirus production, Paul Schwartz and Janet Schukar for their photographic expertise, and Chizuru Kinoshita and Julie Tubb for their technical expertise. We also acknowledge Drs. Mark Johnson and Charles Kuntz for critically reading this manuscript.

Correspondence should be addressed to Dr. Richard Morrison, Department of Neurological Surgery, University of Washington School of Medicine, Box 356470, Seattle, Washington 98195-6470.

Copyright (C) 1998 Society for Neuroscience $\quad 0270-6474 / 98 / 181363-11 \$ 05.00 / 0$ damage after focal ischemia (Crumrine et al., 1994), seizure induction (Morrison et al., 1996), and DNA damage (Wood and Youle, 1995; Enokido et al., 1996a,b). Furthermore, the absence or suppression of p53 expression has been shown to protect cultured neurons from excitotoxin-mediated (H. Xiang et al., 1996) and spontaneous cell death (Eizenberg et al., 1996). Conversely, overexpression of p53, mediated by adenoviral gene delivery, induced neuronal cell death with features characteristic of apoptosis (H. Xiang et al., 1996; Jordan et al., 1997).

These results demonstrate a direct relationship between $\mathrm{p} 53$ expression and loss of viability in CNS neurons, but the biochemical and molecular mechanisms by which p53 promotes neuronal cell death are not understood. The p53 protein functions as a site-specific transactivator of transcription (Kern et al., 1991; Farmer et al., 1992; Zambetti et al., 1992) and has been shown to activate the proapoptotic gene, Bax (Miyashita et al., 1994; Miyashita and Reed, 1995). Bax belongs to a family of structurally related genes that actively regulate cell viability (Knudson and Korsmeyer, 1997; Reed, 1997). This gene family consists of both apoptosis-promoting and apoptosis-inhibiting molecules. It has been proposed that the threshold for apoptosis is dictated by the ratio of death agonists to antagonists (Oltvai et al., 1993; Oltvai and Korsmeyer, 1994). Bax generally functions as a cell death agonist, and elevated levels of Bax have been shown to promote apoptosis in response to numerous cell death-inducing stimuli (Oltvai et al., 1993; Oltvai and Korsmeyer, 1994). The relationship of Bax to p53-mediated apoptosis appears to vary with cell type (Knudson et al., 1995; McCurrach et al., 1997; Yin et al., 1997).

The significance of the Bax protein to some forms of neuronal apoptosis has been demonstrated by the analysis of Bax-deficient 
mice (Knudson et al., 1995). The absence of Bax leads to a reduction in the magnitude of naturally occurring programmed cell death in sympathetic and facial motor neurons (Knudson et al., 1995; Deckwerth et al., 1996). Bax-deficient sympathetic neurons survive NGF withdrawal, and neonatal motor neurons survive disconnection from their targets by axotomy, suggesting that Bax is required for trophic factor deprivation-induced neuronal cell death. Because the p53 gene does not appear to regulate neuronal cell death after trophic factor deprivation (Davies and Rosenthal, 1994; Wood and Youle, 1995; Sadoul et al., 1996), the relationship of Bax to p53-mediated cell death in neurons is not clear. In the present study we evaluated whether there is a relationship between p53-mediated cell death and Bax expression in cortical neurons. Neurons deficient in Bax were protected from cell death induced by excitotoxicity and DNA damage. Glutamate exposure, but not direct DNA damage, produced a significant increase in the levels of Bax protein, which was dependent on the presence of the p53 gene. However, increasing p53 expression in wild-type cortical neurons, using adenovirus-mediated transduction, did not change the levels of Bax protein; moreover, increasing p53 expression in Bax-deficient cortical neurons also produced neuronal cell death. These results suggest that excitotoxicity and DNA damage may initiate multiple cell death transduction pathways and that p53-induced cell death in neurons is coupled to, but is not mediated exclusively by, Bax.

\section{MATERIALS AND METHODS}

p53- and Bax-deficient mice. Mice deficient in the p53 tumor suppressor gene were generated from a $129 / \mathrm{Sv} \times \mathrm{C} 57 \mathrm{BL} / 6$ background, as previously described (Donehower et al., 1992). Mice deficient in the Bax gene were generated from a $129 / \mathrm{Sv} \times \mathrm{C} 3 \mathrm{H}$ background, as previously described (Knudson et al., 1995). Matings generally were performed between two $+/+$ mice (for p53 or Bax $+/+$ offspring) or between p53 $(+/-)$ mice and p53 $(-/-)$ (for p53 $+/-$ and $-/-$ offspring). Two $(+/-)$ mice were mated to obtain Bax $(+/-)$ and $(-/-)$ offspring (Knudson et al., 1995). The genotypes of the mating pairs and all offspring were confirmed by using PCR and DNA extracted from mouse tails (Timme and Thompson, 1994; Deckwerth et al., 1996). p53 or Bax offspring were genotyped three separate times to insure the correct assignment.

Preparation of neuronal cultures. Cortical neurons were prepared as described (H. Xiang et al., 1996) from the brains of p53 or Bax wild-type and deficient newborn mice. Individual cells were dissociated initially by trypsinization $\left(0.125 \%\right.$ in $\mathrm{HBSS}, \mathrm{Ca}^{2+}$ - and $\mathrm{Mg}^{2+}$-free) for $25 \mathrm{~min}$ at $37^{\circ} \mathrm{C}$ and washed once with HBSS containing $\mathrm{Ca}^{2+}$ and $\mathrm{Mg}^{2+}$ after inactivating the enzyme with trypsin inhibitor. Cells were dissociated further in serum-free Neurobasal medium plus B27 supplement (Life Technologies, Gaithersburg, MD) as previously described (Brewer et al., 1993 ) by sequential mechanical dissociation, using a Pasteur pipette with the tip barely fire-polished. Then cells were mixed with an equal volume of trypan blue, and dye-excluding cells were counted in a hemocytometer. Cells were plated on poly-D-lysine-coated dishes $(1 \mu \mathrm{g} / \mathrm{ml})$ at $5.6 \times$ $10^{4}$ cells per $\mathrm{cm}^{2}$ in serum-free Neurobasal medium plus B27 supplement and maintained at $37^{\circ} \mathrm{C}$ in $5 \% \mathrm{CO}_{2}$. Neurobasal medium and $\mathrm{B} 27$ supplement represent an optimized medium for sustaining the survival of CNS neurons (Brewer et al., 1993). The medium supports long-term survival (several weeks) and suppresses glial growth to $<2 \%$ of the total cell population. Intense immunoreactivity for the neurofilament protein was detected consistently in $98 \%$ or more of all cells from both the p53 (H. Xiang et al., 1996) and Bax strains (data not shown). The absence of astrocytes was confirmed by the lack of GFAP staining, as previously described (H. Xiang et al., 1996).

Determination of neuronal cell number. The number of viable neurons in a well was determined by counting cells within two premarked reticules $\left(1 \mathrm{~mm}^{2}\right)$ at the time of treatment and at various times after treatment. Viable neurons were identified according to the following criteria: (1) neurites were uniform in diameter, smooth in appearance, and at least twice as long as the soma; and (2) somata were normally smooth and round to oval-shaped. In contrast, degenerating, nonviable neurons possessed neurites that were fragmented and "beaded," and the soma was rough, condensed, vacuolated, and irregularly shaped.
MTT assay. The conversion of the yellow tetrazolium salt [3(4,5dimethylthiazol-2-yl)-2,5-diphenyltetrazolium bromide, MTT] to the purple formazan dye is dependent on the activity of mitochondrial dehydrogenases and is, therefore, reflective of mitochondrial status (Slater et al., 1963; Altman, 1976). Assay of the conversion of MTT to purple formazan crystals was performed according to the manufacturer's specifications (MTT Kit I, Boehringer Mannheim, Indianapolis, IN). Briefly, $50 \mu \mathrm{l}$ of the $5 \mathrm{mg} / \mathrm{ml}$ MTT labeling reagent was added to each well of neurons (along with $500 \mu \mathrm{l}$ of medium). The cultures were incubated for $4 \mathrm{hr}$ in a humidified atmosphere at $37^{\circ} \mathrm{C}, 5 \% \mathrm{CO}_{2}$. The purple formazan salt was solubilized in $500 \mu \mathrm{l}$ of a solution containing $10 \%$ SDS and $0.01 \mathrm{M} \mathrm{HCl}$. The solution was allowed to stand in the wells overnight in a humidified atmosphere at $37^{\circ} \mathrm{C}, 5 \% \mathrm{CO}_{2}$. The spectrophotometric absorbance of the samples was determined at a wavelength of $550 \mathrm{~nm}$ and $690 \mathrm{~nm}$ (reference wavelength). The amount of MTT conversion was displayed as a percentage of the absorbance measured in treated wells relative to the absorbance measured in saline or DMSO control wells.

Live-dead cell assay. The presence of live or dead neurons also was evaluated by using two fluorescent indicators of membrane integrity (Molecular Probes, Eugene, OR). Calcein-AM is a fluorogenic esterase substrate that is hydrolyzed to a green fluorescent product and retained by cells with an intact membrane. Ethidium homodimer-1 is a highaffinity red fluorescent nucleic acid stain that is able to pass only through the permeant membranes of dead cells. At various times after treatment the neurons were administered a solution containing calcein-AM $(4 \mu \mathrm{M})$ and ethidium homodimer-1 $(2 \mu \mathrm{M})$ and incubated for $30 \mathrm{~min}$ at room temperature before being viewed under epifluorescence optics with fluorescein (calcein) and rhodamine (ethidium homodimer-1) filters.

Preparation and titration of adenovirus vectors. Nonreplicative recombinant adenovirus deleted in the E1 region, carrying the human wildtype p53 gene under the control of the cytomegalovirus (CMV) promoter, was generated as previously described (Zhang et al., 1993) and was generously provided by Dr. Toshiyoshi Fujiwara (Okayama University Medical School, Japan). The adenovirus carrying a $\beta$-galactosidase gene, AxCALacZ (Kanegae et al., 1995), was kindly provided by Drs. Saito and Kanegae (University of Tokyo, Tokyo, Japan). Recombinant adenovirus was propagated in E1 complementing human embryonic kidney 293 cells. Viral stocks were purified in cesium chloride gradients and titered according to the method of Barr et al. (1995).

Preparation of cell extracts and Western blot analysis. Cultured neurons were lysed in a buffer of $50 \mathrm{~mm}$ Tris- $\mathrm{HCl}, \mathrm{pH} 7.4,150 \mathrm{~mm} \mathrm{NaCl}, 1 \%$ sodium deoxycholate, $0.1 \%$ SDS, and $1 \%$ Triton X-100 containing the protease inhibitors leupeptin $(5 \mu \mathrm{g} / \mathrm{ml})$, PMSF $(1 \mathrm{~mm})$, pepstatin (7 $\mu \mathrm{g} / \mathrm{ml})$, and aprotinin $(5 \mu \mathrm{g} / \mathrm{ml})$ (Boehringer Mannheim). The cell lysate was centrifuged at $14,000 \times g$ for $15 \mathrm{~min}$. The supernatant was removed and stored at $-80^{\circ} \mathrm{C}$. Aliquots were taken for protein determinations by using the Bio-Rad (Hercules, CA) protein assay dye reagent. Cell extracts containing equivalent amounts of protein were boiled for $5 \mathrm{~min}$ in sample buffer containing 5\% 2-mercaptoethanol/2\% SDS and analyzed by SDS-PAGE.

After SDS-PAGE using a $12 \%$ gel, neuronal extracts were transferred to a nitrocellulose membrane, as previously described (Giordano et al., 1992). Nonspecific sites were blocked by incubating nitrocellulose in PBS containing 5\% nonfat dry milk. Blots were incubated overnight at room temperature with a rabbit anti-Bax polyclonal antibody (1:100, number 20651; J. Xiang et al., 1996), a mouse anti-human p53 monoclonal antibody (1:500, Ab-2; Oncogene Sciences, Cambridge, MA), or a mouse anti- $\beta$-actin monoclonal antibody (1:10,000; Sigma, St. Louis, MO). Blots were washed with PBS once, twice in $0.05 \%$ NP-40/PBS, once more in PBS for $10 \mathrm{~min}$ each, and subsequently incubated with a biotinconjugated horse anti-mouse (Vector Laboratories, Burlingame, CA) or goat anti-rabbit (Jackson ImmunoResearch Laboratories, West Grove, PA) IgG secondary antibody (1:500) for $2 \mathrm{hr}$ at room temperature. The blots were washed as before and subsequently incubated with an avidinbiotinylated horseradish peroxidase complex (Vectastain Elite ABC, 1:50; Vector Laboratories) in 5\% nonfat dry milk in PBS for $1 \mathrm{hr}$ at room temperature. Then the blots were washed four times as described above. Immunoreactive bands were visualized by developing the blot with Amersham ECL reagents (Arlington Heights, IL) according to the manufacturer's specifications. After a $10 \mathrm{~min}$ exposure to the ECL reagents, the blots were exposed to x-ray film for 1-10 min. After the detection of either Bax or $\mathrm{p} 53$ protein expression, the blot was reprobed with a mouse anti- $\beta$-actin monoclonal antibody. Molecular weights were determined by comparison with biotinylated markers (Bio-Rad). 


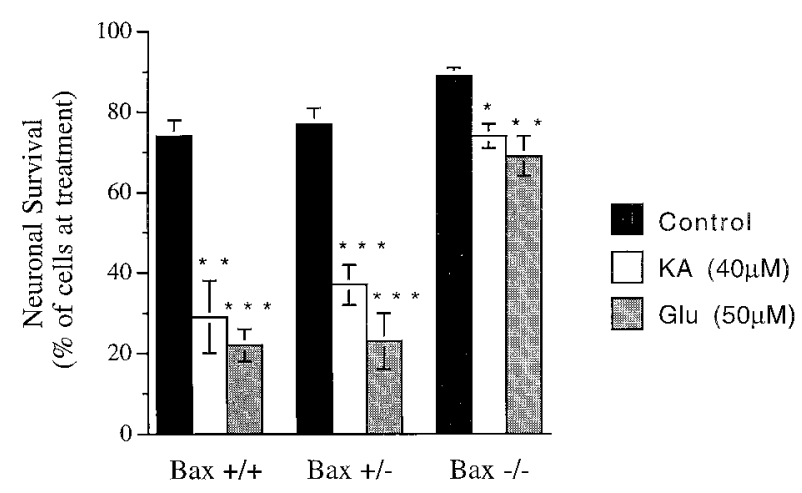

Figure 1. The absence of Bax confers resistance to glutamate- and kainate-mediated cell death. Cortical neurons containing Bax $(+/+$ and $+/-)$ or those deficient in Bax $(-/-)$ were plated and maintained in basal culture conditions for $4 \mathrm{~d}$, as described in Materials and Methods. Cells subsequently were maintained in medium alone (Control) or treated with glutamate $(G l u, 50 \mu \mathrm{M})$ or kainate $(K A, 40 \mu \mathrm{M})$. The cultures were exposed continuously to excitotoxin, and the number of viable neurons then was determined after a $3 \mathrm{~d}$ treatment period. Neuronal survival data are expressed relative to the number of cells at the time of treatment. All data are the mean \pm SD of 10 or more experiments. The Bax $(+/+)$ and $(+/-)$ genotypes showed significant differences between nontreated cells (Control) and cells treated with glutamate $(* * * p<0.001$, ANOVA) or kainate $(* * p<0.001$, ANOVA). Neuronal survival in Bax $(-/-)$ cultures also differed significantly between nontreated conditions (Control) and glutamate-treated $(* p<0.01$, ANOVA) and kainate-treated $(* * p<0.001$ ANOVA) conditions. Neuronal survival in glutamate- and kainatetreated Bax $(-/-)$ cultures differed significantly from Bax $(+/+)$ and $\mathrm{Bax}$ $(+/-)$ cultures similarly treated (Glu, $p<0.005 ; K A, p<0.005$, ANOVA).

\section{RESULTS}

\section{Neurons lacking Bax are resistant to excitotoxicity and DNA damage}

We recently have postulated a direct role for p53 in initiating neuronal degeneration on the basis of the observation that wildtype (p53+/+) neurons were extremely susceptible to glutamateand kainate-mediated cell death, whereas p53-deficient $(-/-)$ neurons were resistant (H. Xiang et al., 1996). We reasoned that if Bax activity were essential to a cell death pathway activated by p53 in response to excitotoxic challenge, then Bax-deficient neurons should display a degree of resistance similar to that of the p53-deficient neurons. Glutamate (Glu) or kainate (KA) administration induced cell death in cortical neuronal cultures derived from newborn Bax $(+/+)$ mice (Fig. 1), with both a time and a dose dependence (data not shown). A significant difference in the percentage of surviving neurons was observed between control and Glu- or KA-treated neurons as early as $24 \mathrm{hr}$, with this difference becoming more pronounced with time. Approximately $70-80 \%$ of $\mathrm{Bax}(+/+)$ neurons present at the time of treatment had died $3 \mathrm{~d}$ after adding Glu $(50 \mu \mathrm{M})$ or KA $(40 \mu \mathrm{M})$. The extent of neuronal death induced by Glu or KA did not differ significantly between $\operatorname{Bax}(+/+)$ and $\operatorname{Bax}(+/-)$ neuronal cultures $(p>$ $0.55)$ (Fig. 1). The morphological changes induced by Glu treatment were striking. Nontreated wild-type cultures consisted primarily of intact cell bodies, which were demonstrable by phasecontrast optics or by detection of the viability dye, calcein (Fig. $2 A$, Control, green fluorescence). Nontreated wild-type neurons displayed an abundant outgrowth of arborizing neurites that were visualized clearly by the calcein fluorescence. However, even at $1 \mathrm{~d}$ after Glu treatment $(50 \mu \mathrm{M})$ there was significant loss of viable cell bodies, as visualized by phase-contrast optics and demon- strated by the reduced number of elements exhibiting calcein fluorescence (Fig. 2A, Glutamate). Many cell bodies that remained after Glu treatment were damaged severely, as demonstrated by their uptake of ethidium homodimer (red fluorescence).

The loss of viability induced by KA or Glu treatment was determined not only by direct cell counting but also by evaluating mitochondrial integrity as assessed by conversion of the tetrazolium salt, MTT, to formazan by the respiratory chain enzyme succinate-tetrazolium reductase (Slater et al., 1963; Altman, 1976). Treatment of Bax $(+/+)$ cortical neurons with Glu $(50 \mu \mathrm{M})$ or KA $(40 \mu \mathrm{M})$ for $5 \mathrm{~d}$ produced a significant reduction in MTT conversion (Table 1; glutamate, $29 \%$ of control; kainate, $77 \%$ of control) relative to nontreated control cultures.

Neurons deficient in Bax $(-/-)$ were resistant to Glu- and KA-induced cell death relative to Bax wild-type neurons (Fig. 1). However, in contrast to p53-deficient neurons (H. Xiang et al., 1996), there was a small but significant decline in the percentage $(20 \%)$ of $\operatorname{Bax}(-/-)$ neurons that survived $3 \mathrm{~d}$ after exposure to Glu $(50 \mu \mathrm{M})$ or KA $(40 \mu \mathrm{M})$, as compared with control cultures (i.e., nontreated) (Glu, $p<0.01$; KA, $p<0.001$ ). A decline in viability of Bax (-/-) neurons exposed to Glu for $5 \mathrm{~d}$ was confirmed by the reduction in MTT conversion (Table 1; glutamate, $65 \%$ of control). Thus, the protection afforded by Bax deletion was relative to controls, but not absolute. The protection conferred by the absence of Bax was consistent with the lack of substantial morphological damage observed in the cultures; whereas Bax $(+/+)$ neurons displayed obvious signs of damage, most Bax $(-/-)$ neurons retained viable cell bodies and neurites after excitotoxic challenge (Fig. 2B, compare Control and Glutamate). The viability of Bax $(-/-)$ neurons also was reflected in the retention of calcein fluorescence.

The resistance displayed by Bax-deficient cortical neurons to excitotoxic injury was not restricted to this single form of damage. In the present study Bax- and p53-deficient cortical neurons also were protected from DNA damage induced by the addition of the topoisomerase I inhibitor, camptothecin. The cellular toxicity of camptothecin is associated with the generation of DNA strand breaks (Ryan et al., 1991). Camptothecin treatment, which leads to cell cycle arrest or apoptosis, has been shown to elevate p53 protein levels (X. Chen et al., 1996; M. Johnson and R. Morrison, unpublished data). In cultures of p53 (Fig. $3 A,+/+$ ) and Bax (Figs. $2 A, 3 B,+/+$ ) wild-type cortical neurons, camptothecin exposure produced significant cell death. Camptothecin-induced cell death was dose-dependent and proceeded more rapidly $(2 \mathrm{~d})$ than cell death induced by Glu $(50 \mu \mathrm{M})$ treatment $(3-4 \mathrm{~d})$. Morphological evidence of neuronal damage was observed clearly at $24 \mathrm{hr}$ after treatment and was associated with significant loss of viable cell bodies, as seen under phase-contrast optics and by the paucity of calcein fluorescence (Fig. 2A, Camptothecin). The majority of cell bodies that remained after camptothecin treatment was severely damaged, as demonstrated by their uptake of ethidium homodimer (red fluorescence).

The significant degree of damage produced by camptothecin treatment in $\mathrm{Bax}(+/+)$ cultures was reflected in the absence of detectable MTT conversion (Table 1). Interestingly, the damage induced by camptothecin and glutamate was not associated with DNA laddering (data not shown), consistent with previous studies (Ankarcrona et al., 1995; Finiels et al., 1995). In marked contrast, camptothecin treatment did not significantly alter the survival of p53- and Bax-deficient cortical neurons when compared with nontreated or DMSO-treated control neurons (Figs. 


\section{(A) Bax Wild-Type}

Control
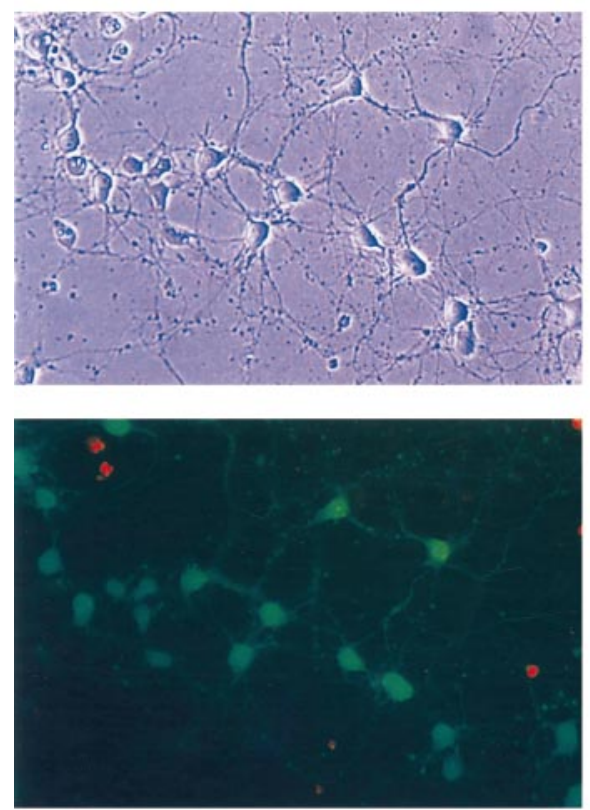

\section{Glutamate}
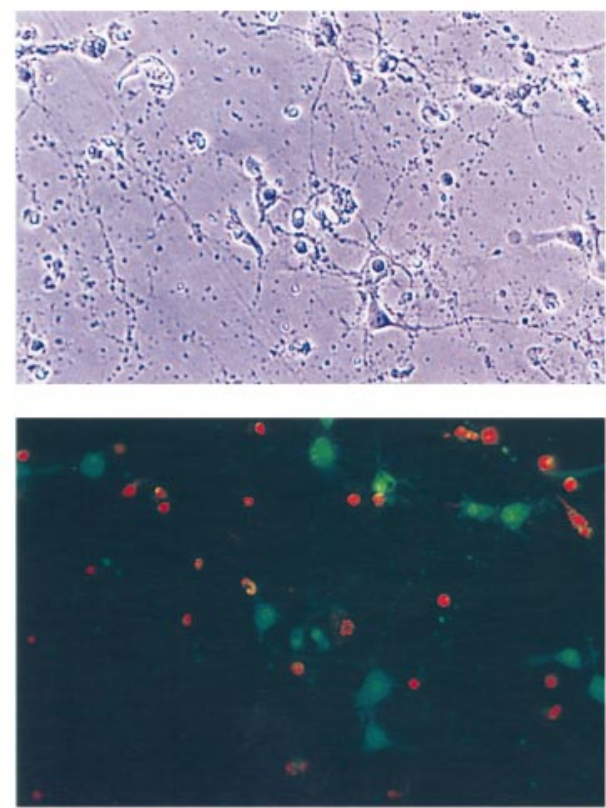

Camptothecin
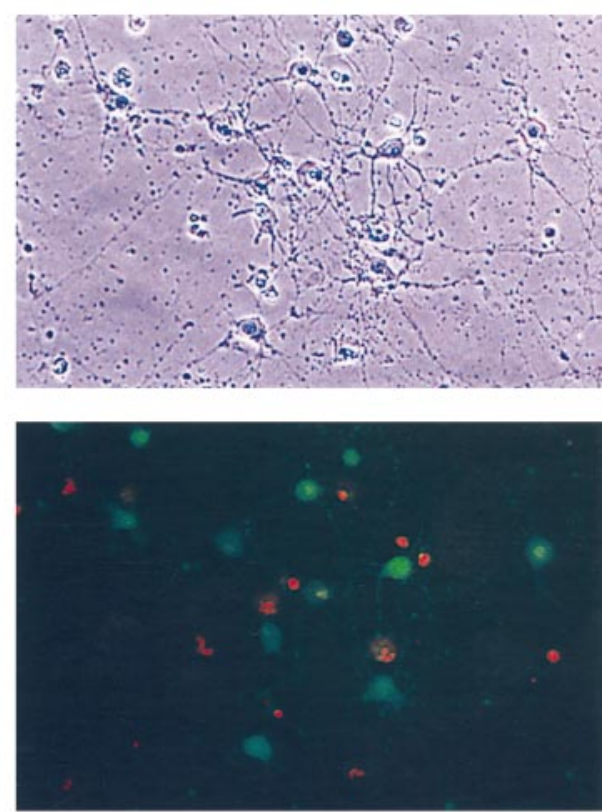

\section{(B) Bax Deficient}

\section{Control}
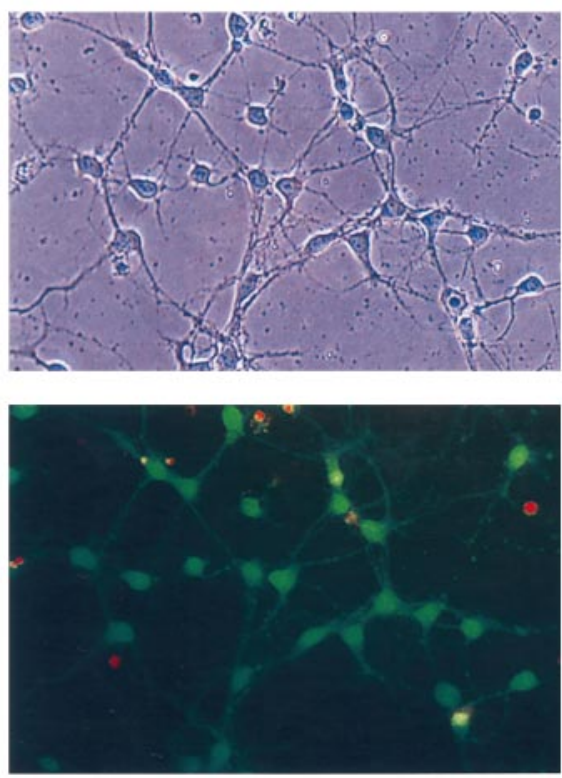

\section{Glutamate}
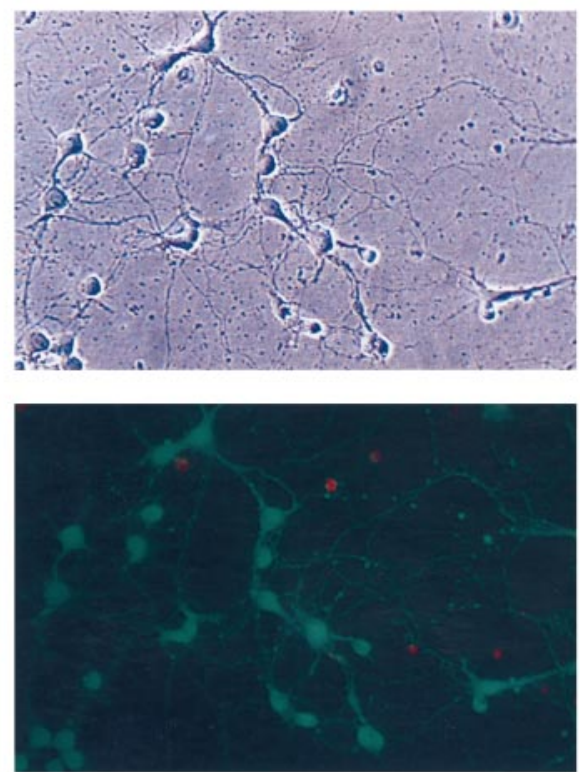

Camptothecin
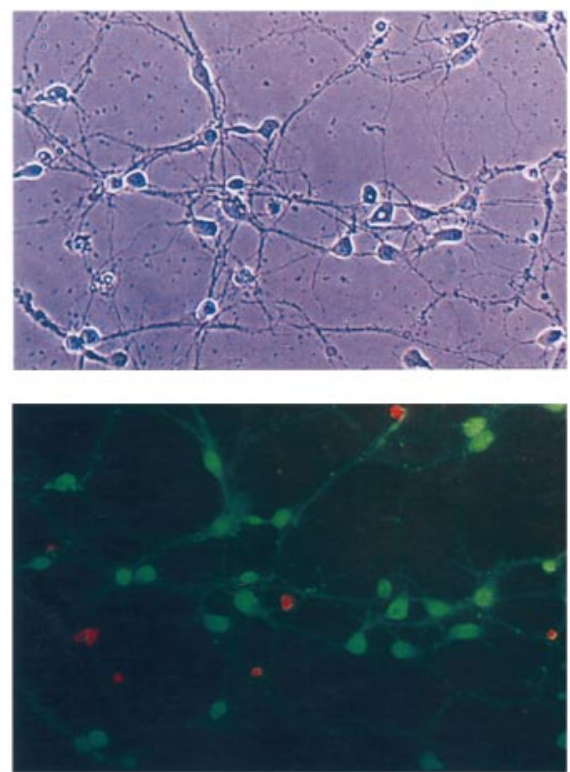

Figure 2. Injury-induced alterations in neuronal morphology and viability are dependent on the presence of Bax. Neurons containing both Bax alleles ( $A$, wild-type) or those deficient in $\operatorname{Bax}(B)$ were plated and maintained in basal culture conditions for $4 \mathrm{~d}$, as described in Materials and Methods. Cells subsequently were maintained in medium alone (Control) or treated with a single dose of glutamate $(50 \mu \mathrm{M})$ or camptothecin $(5 \mu \mathrm{M})$. One day after treatment, calcein-AM and ethidium homodimer-1 were added to the culture medium, and the cells were processed and analyzed as described in Materials and Methods. Cells were viewed with phase-contrast optics (top panels) or viewed with fluorescein and rhodamine optics (bottom panels) as a double exposure. Calcein-positive cells ( green fluorescence) indicate healthy cells with an intact plasma membrane, whereas ethidium homodimer-1positive cells (orange fluorescence) represent dead or severely damaged cells. The top and bottom panels depict the same field for a given condition. The results are representative of four separate experiments, each performed with newly established primary cultures. Magnification, $170 \times$. 
Table 1. MTT activity measurements in cultured primary cortical neurons after glutamate and camptothecin treatment

\begin{tabular}{lll} 
Genotype & $\begin{array}{l}\text { Treatment } \\
(n=4)\end{array}$ & $\begin{array}{l}\text { MTT activity } \\
(\% \text { of control } \pm \text { SEM })\end{array}$ \\
\hline Bax $+/+$ & Glutamate $(50 \mu \mathrm{M})$ & $29 \pm 3.5$ \\
& Kainate $(40 \mu \mathrm{M})$ & $77 \pm 4.0$ \\
Camptothecin $(5 \mu \mathrm{M})$ & $\mathrm{ND}$ \\
Bax $-/-$ & Glutamate $(50 \mu \mathrm{M})$ & $65 \pm 2.4$ \\
& Kainate $(40 \mu \mathrm{M})$ & $93 \pm 2.1$ \\
& Camptothecin $(5 \mu \mathrm{M})$ & $80 \pm 7.6$
\end{tabular}

MTT activity was determined for control and treated cultures, as described in Materials and Methods. Cultures were established and maintained for $4 \mathrm{~d}$ before treatment. MTT determinations were performed $5 \mathrm{~d}$ after glutamate and kainate treatment and $2 \mathrm{~d}$ after camptothecin treatment. Saline and DMSO represented vehicle controls for glutamate and camptothecin, respectively. The final concentration of DMSO in the culture medium was $0.01 \%$. Results are expressed as the percentage of MTT activity in the treated cultures relative to the appropriate vehicle control. ND, Not detectable.

$2 A, B, 3 A, B)$. Bax- and p53-deficient neurons appeared remarkably healthy $2 \mathrm{~d}$ after camptothecin treatment and showed no morphological evidence of damage. Cell bodies failed to exhibit condensation, and neurites did not display the blebbing and disintegration (Fig. $2 B$ ) that were prominent in camptothecintreated wild-type cultures (Fig. $2 A$ ). The enhanced viability of Bax $(-/-)$ neurons relative to wild-type neurons after camptothecin treatment was consistent with the high level of MTT conversion present in the Bax $(-/-)$ cultures (Table 1$)$.

\section{The Bax protein in cultured cortical neurons is selectively elevated by excitotoxic injury}

The resistance displayed by p53- and Bax-deficient neurons to Glu- and camptothecin-mediated cell death suggested that these forms of toxicity must be capable of altering the levels, activity, or intracellular distribution of the Bax protein. Because the Bax promoter previously has been shown to contain a p53-responsive binding element (Miyashita et al., 1994), we therefore examined cortical neurons for alterations in the levels of Bax protein after
Glu and camptothecin treatment. Glutamate treatment $(50 \mu \mathrm{M})$ produced a significant increase in the steady-state levels of the Bax protein in neurons containing the p53 gene (Fig. 4, Table 2). The levels of Bax protein increased $\sim 18$-fold in Glu-treated cultures relative to saline-treated control cultures $(n=3 ; p<$ 0.05 ) and were evident $24 \mathrm{hr}$ after treatment. In contrast to the dramatic change induced by Glu, camptothecin induced a small change in the steady-state levels of Bax protein (Fig. 4, Table 2). The Glu-induced increase in Bax protein was not observed when this treatment was imposed on p53-deficient neurons (Fig. 4, p53 $-/-, n=4)$, suggesting that p53 was needed to mediate the rise in Bax protein. Neurons containing a full complement of p53 alleles $(\mathrm{p} 53+/+)$ were derived from both the p53 and Bax strains of mice. Therefore, the p53-dependent glutamate-induced increase in Bax protein was a general phenomenon observed in neurons derived from at least two distinct strains of mice. However, increased p53 expression resulting from adenovirusmediated gene transfer was not sufficient, by itself, to elevate Bax protein levels (Fig. 4, p53 $\mathrm{ADV}$ ). This result suggests that other pathways must be required, in addition to $\mathrm{p} 53$ expression, for Glu to promote an increase in the steady-state levels of the Bax protein. These results suggest that neuronal viability may be compromised by complex p53-mediated effects on the Bax protein.

\section{p53 induces neuronal cell death via a complex signaling cascade}

Previous studies from this laboratory demonstrated that increased p53 expression was sufficient to induce neuronal cell death, even in the absence of a cytotoxic stimulus (H. Xiang et al., 1996). The same study showed that, although p53-deficient neurons were resistant to excitotoxic injury, they were still competent to respond to a $\mathrm{p} 53$-initiated cell death pathway after introduction of the p53 gene via adenovirus-mediated transduction. In the present study the same paradigm was used to determine whether Bax is essential to a p53-regulated cell death pathway in neurons. A control virus containing the $\beta$-galactosidase gene (LacZ) was used previously to determine the efficiency of transduction as well

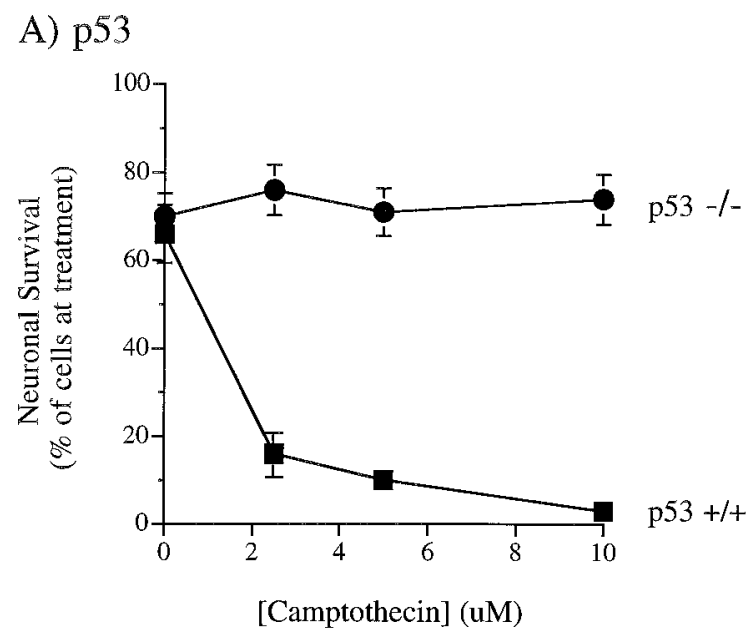

B) Bax

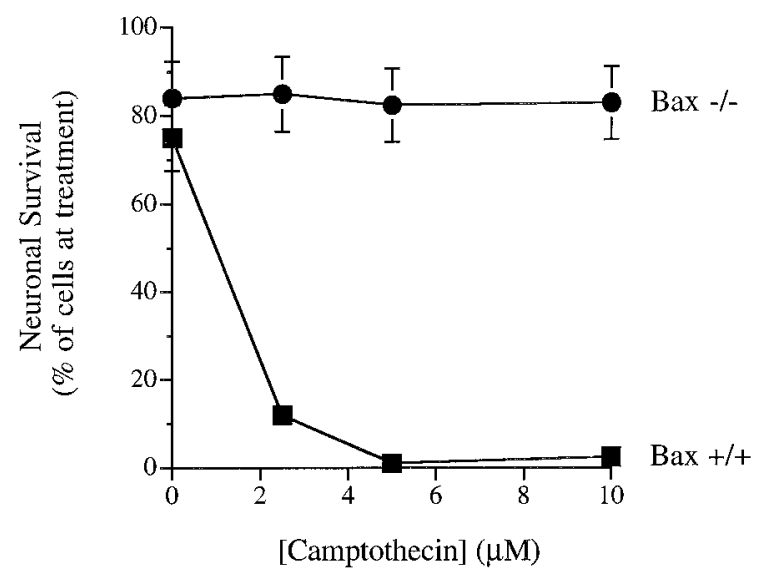

Figure 3. The absence of p53 or Bax confers resistance to camptothecin-mediated cell death in cortical neurons. Cortical neurons were plated, maintained, and treated as described in Materials and Methods. Neurons were derived from either the p53 strain of mice $(A)(\mathrm{p} 53+/+, \mathbf{\square} ; \mathrm{p} 53(-/-$, -) or the Bax strain of mice $(B)($ Bax $+/+, \mathbf{\square}$; Bax $-/-, \mathbf{0})$. Cells subsequently were maintained in medium alone or treated with varying concentrations of camptothecin. Neuronal survival was assessed $2 \mathrm{~d}$ later by counting the number of viable neurons according to the criteria described in Materials and Methods. All data are the mean \pm SD of six samples. Some data points do not express SD bars because they are small enough to be contained within the symbols. Neurons containing p53 $(+/+, A)$ or $\operatorname{Bax}(+/+, B)$ showed significant differences in survival when compared with cells deficient in $\mathrm{p} 53$ ( $-/-$, $A)$ or Bax $(-/-, B)$ after camptothecin treatment $(p<0.001$, ANOVA). 


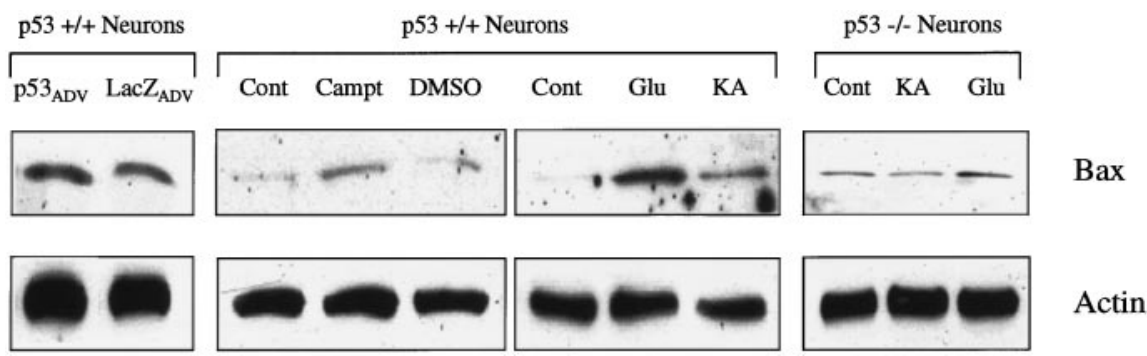

Figure 4. Glutamate exposure elevates Bax protein levels in a p53-dependent manner. Cortical neurons derived from either the p53 strain or the Bax strain of mice were plated and maintained as described in Materials and Methods. All of the cell extracts depicted in this figure were derived from tissues that were homozygous-positive for the Bax alleles $(\mathrm{Bax}+/+)$. At $4 \mathrm{~d}$ after plating, the cells were treated with saline (vehicle control, glutamate), DMSO (vehicle control, camptothecin), glutamate (Glu, $50 \mu \mathrm{M})$, or camptothecin (Campt, $5 \mu \mathrm{M}$ ) or were infected with adenovirus expressing the wild-type human 553 gene ( $p 53_{\mathrm{ADV}}$, multiplicity of infection-500). Cellular extracts were prepared $24 \mathrm{hr}$ after treatment or $2 \mathrm{~d}$ after adenovirus infection. Samples (50 $\mu \mathrm{g}$ of protein/lane) were resolved by SDS-PAGE, and immunoblotting was performed with the Bax antibody, as described in Materials and Methods. Exposure time varied from 1-10 min, accounting for some of the variability in the band intensity of control samples. The results are representative of five separate experiments. After the blots were probed for Bax protein, they were reprobed for $\beta$-actin (Actin) protein to control for the relative amount of protein loaded in each lane.

Table 2. Glutamate elevates Bax protein in a p53-dependent manner in cultured primary cortical neurons

\begin{tabular}{lll} 
p53 status & $\begin{array}{l}\text { Treatment } \\
(n=3)\end{array}$ & $\begin{array}{l}\text { Bax protein } \\
\text { (fold increase } \pm \text { SEM) }\end{array}$ \\
\hline p53+/+ & Glutamate $(50 \mu \mathrm{M})$ & $17.8 \pm 3.1$ \\
& Kainate $(40 \mu \mathrm{M})$ & $7.1 \pm 2.8$ \\
p53-/- & Camptothecin $(5 \mu \mathrm{M})$ & $1.6 \pm 0.4$ \\
& Glutamate $(50 \mu \mathrm{M})$ & $1.2 \pm 0.2$ \\
& Kainate $(40 \mu \mathrm{M})$ & $1.1 \pm 0.1$ \\
& Camptothecin $(5 \mu \mathrm{M})$ & $1.2 \pm 0.1$
\end{tabular}

Cultures were established and maintained for $4 \mathrm{~d}$ before treatment. Protein extracts were prepared $24 \mathrm{hr}$ after treatment, and Western blot analysis was performed for Bax and $\beta$-actin proteins, as described in Materials and Methods. Bax protein levels were determined from densitometric scans of the exposed $x$-ray films and normalized against the levels of $\beta$-actin. The fold increase was determined by dividing the $\mathrm{Bax} / \beta$-actin ratio for treated cultures by the same ratio determined for saline (for Glu) or DMSO (for camptothecin) treated controls. Results are expressed as the mean fold increase \pm SEM and represent the results of three separate determinations derived from different cellular extracts.

as the effect of viral infection on neuronal viability $(H$. Xiang et al., 1996). These results demonstrated that neurons could be infected with a high degree of efficiency by using adenovirus and that at the appropriate titer the infection process by itself does not alter neuronal survival.

Adenoviral infection at a multiplicity of infection (MOI) of 250 was shown previously to produce significant neuronal cell death in p53-deficient neurons (5\% survival $4 \mathrm{~d}$ postinfection; $\mathrm{H}$. Xiang et al., 1996). In the present study the p53 adenovirus did not affect the viability of Bax-deficient neurons when used at a titer of 250 (Fig. 5, p53, MOI-250). However, this resistance to introduction of p53 was not absolute. When the p53 adenovirus titer was increased to an MOI of 500, Bax-deficient (Bax -/-) neurons developed pathological morphology (Fig. 6A, p53-Adenovirus) and showed a dramatic decline in survival (Fig. 5, p53, MOI-500). At $4 \mathrm{~d}$ after infection only $25 \%$ of the $\operatorname{Bax}(-/-)$ neurons present at the time of infection survived (MOI-500). This decline in viability was confirmed by the loss of calcein fluorescence (Fig. $6 C$, green fluorescence) and by the increased uptake of ethidium homodimer (Fig. 6C, red fluorescence). The morphological appearance of neurons in the p53 adenovirus-infected cultures was consistent with their declining viability. Most noticeable was the blebbing and dissolution of neuritic processes, followed by shrinkage of the soma and condensation of the nucleus. Because infec-

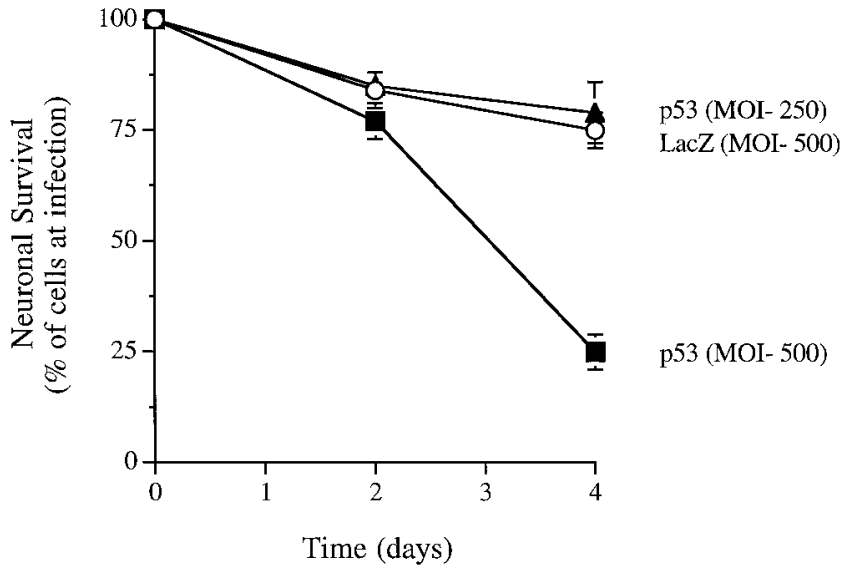

Figure 5. p53-induced neuronal cell death can occur independently of Bax expression. Cortical neurons $(\mathrm{Bax}-/-$ ) were plated and maintained as described in Materials and Methods. At $4 \mathrm{~d}$ after plating, the cells were infected with adenovirus expressing either the $\beta$-galactosidase gene $(\bigcirc$, LacZ multiplicity of infection $=500)$ or the human wild-type p53 gene $(\boldsymbol{\Delta}$, p53 multiplicity of infection $=250 ; \boldsymbol{\square}$, p53 multiplicity of infection $=500$ ). The number of surviving neurons was determined by counting morphologically viable cells, as described in Materials and Methods, at 2 and $4 \mathrm{~d}$ after infection. The data are expressed as the percentage of neurons surviving relative to the number of neurons present at the time of infection (mean $\pm \mathrm{SD}, n=6$ ). The survival of p53-infected Bax $(-/-$ ) neurons was significantly different from neurons infected with the $\beta$-galactosidase gene $(p<0.001$, ANOVA) when an MOI of 500 was used; at an MOI of 250 there was no difference from control infection $($ LacZ; $p>0.20)$.

tion with an adenovirus containing the $\beta$-galactosidase gene at the higher titer of MOI-500 had only a modest effect on Bax $(-/-)$ neuronal survival on the basis of cell counts of morphologically viable cells (Fig. 5, LacZ, MOI-500) and the continued presence of calcein fluorescence (Fig. $6 \mathrm{D}$, green fluorescence), cell death observed with p53 adenovirus infection was attributed specifically to increased p53 expression.

Despite the different outcomes observed with p53- and Baxdeficient neurons in response to p53 adenovirus infection at an MOI of 250, the amount of p53 protein expressed in both types of neurons was similar (Fig. 7). Further, the extent of p53 expressed after adenovirus infection greatly exceeded the p53 levels induced under physiological conditions of injury. p53Immunoreactive protein could not be detected by Western blot 


\section{Bax Deficient}

\section{p53 - Adenovirus}
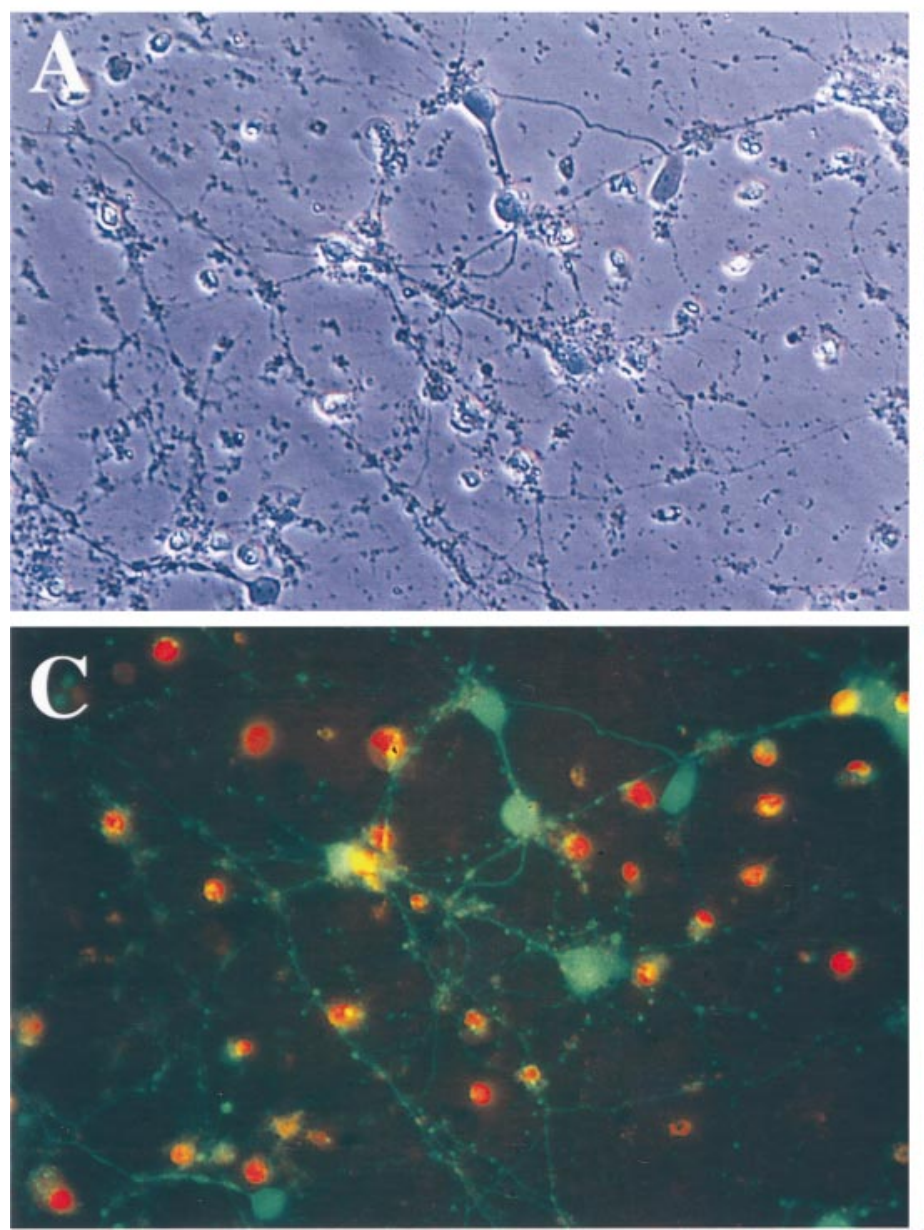

\section{LacZ - Adenovirus}
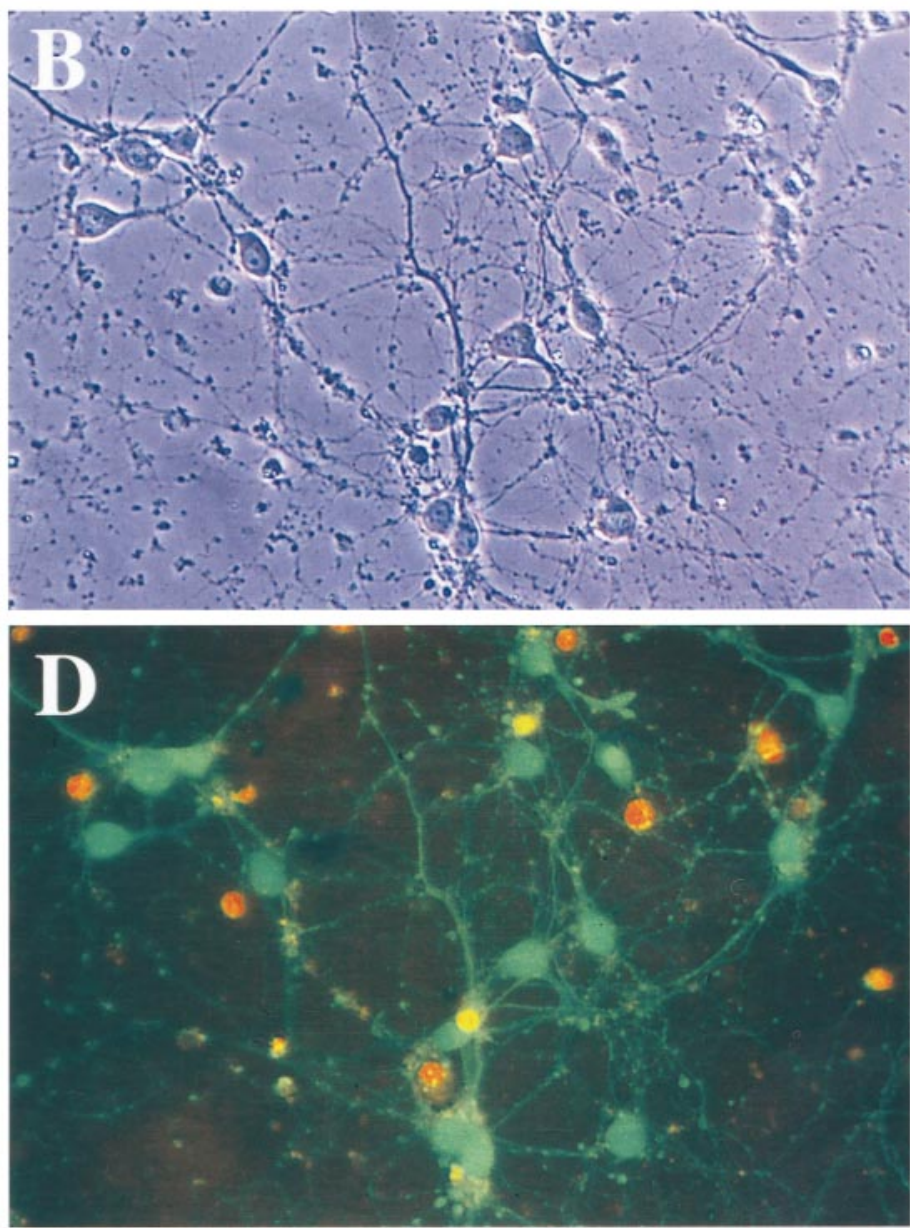

Figure 6. Morphological alterations associated with adenovirus-mediated transduction of the p53 or $\beta$-galactosidase (LacZ) gene into Bax-deficient neurons. Cortical neurons ( $\mathrm{Bax}-/-$ ) were plated and maintained as described in Materials and Methods. At $4 \mathrm{~d}$ after plating, the cells were infected with adenovirus containing the human wild-type p53 gene (multiplicity of infection $=500 ; A, C$ ) or the $\beta$-galactosidase gene (multiplicity of infection $=$ $500 ; B, D)$. Cells were photographed $4 \mathrm{~d}$ after infection. Cells were viewed with phase-contrast optics (top panels) or viewed with fluorescein and rhodamine optics (bottom panels) as a double exposure, as described in the legend to Figure 2. Numerous cell bodies in various states of condensation and degeneration are present in p53-infected cultures $(A, C)$. Magnification, 260×.

analysis after adenovirus infection with the $\beta$-galactosidase gene (Fig. 7, LacZ). We conclude from this study that, under the appropriate circumstances, p53 can induce neuronal cell death in the absence of Bax, suggesting that p53 activates multiple cell death signaling pathways in neurons.

\section{DISCUSSION}

The p53 tumor suppressor gene recently has been implicated as a mediator of neuronal cell death. In the absence of p53, neurons normally damaged in response to ischemic, excitotoxic, or neurotoxic insults are protected (Crumrine et al., 1994; Wood and Youle, 1995; Enokido et al., 1996a,b; Morrison et al., 1996; Sakhi et al., 1996; Trimmer et al., 1996). Conversely, increased p53 expression induces neuronal cell death even in the absence of an injury (H. Xiang et al., 1996; Jordan et al., 1997). The specific signaling intermediates activated in response to p53 induction have not been characterized. In the present study we determined whether the proapop- totic protein Bax, a member of the Bcl-2 family (Oltvai et al., 1993), was required to initiate a p53-dependent cell death pathway in CNS-derived neurons. The Bax gene previously has been shown to exhibit activation in response to increased p53 levels, consistent with the identification of p53-responsive elements in the Bax promoter (Miyashita et al., 1994; Miyashita and Reed, 1995). Evidence obtained from the present investigation suggests that (1) Bax regulates neuronal sensitivity to excitotoxic and genotoxic injury, as does p53 [see H. Xiang et al. (1996) and this study]; (2) the Bax protein may be subject to multiple forms of regulation, in an injury-dependent manner; (3) Bax is not absolutely essential for p53-mediated cell death because very high levels of p53 expression, produced by adenovirus-mediated gene transfer, induced neuronal cell death in the absence of Bax. These results support the view that the p53-mediated cell death pathway in neurons may, at least in some forms of "physiological" insult, depend on alterations in the activity of Bax. 


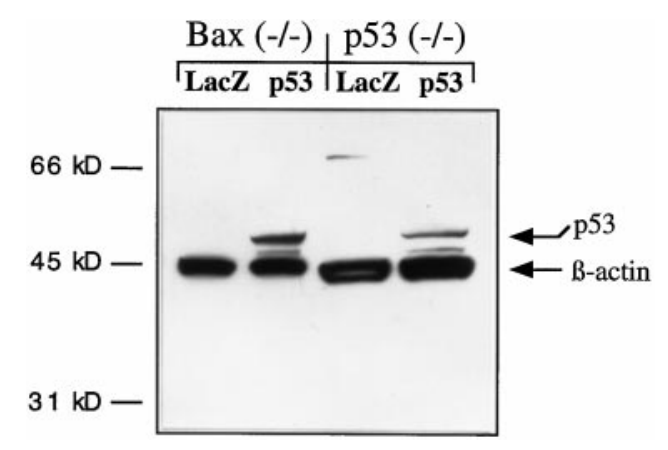

Figure 7. p53 immunoreactivity in Bax- and p53-deficient cortical neurons after infection with adenovirus containing the wild-type human p53 gene. Cortical neurons derived from p53- or Bax-deficient mice were plated and maintained as described in Materials and Methods. At $4 \mathrm{~d}$ after plating, the cells were infected with adenovirus expressing either the $\beta$-galactosidase gene (multiplicity of infection-250, LacZ) or the human wild-type p53 gene (multiplicity of infection-250, p53). Protein extracts were prepared $2 \mathrm{~d}$ after infection. Samples $(50 \mu \mathrm{g}$ of protein/lane) were resolved by SDS-PAGE, and immunoblotting was performed with the Ab-2 p53 antibody, as described in Materials and Methods. Cellular extracts were analyzed simultaneously for expression of the p53 protein ( $p 53)$ and $\beta$-actin ( $\beta$-actin; as a control for the relative amount of protein loaded in each lane). This result is representative of three individual experiments.

\section{Bax-p53 coupling in cell death pathways}

Our results demonstrate that Bax plays a critical role in regulating neuronal sensitivity to excitotoxic and genotoxic damage. Previous results from our laboratory demonstrated that p53-deficient neurons were resistant to glutamate-mediated excitotoxicity. It recently has been shown that excitotoxicity may be associated with the accumulation of single-strand DNA breaks (Didier et al., 1996). Therefore, it is especially noteworthy that Bax- and p53deficient neurons were resistant to the toxic effects of camptothecin, which, at the concentrations used in this study, directly promotes DNA strand breaks (Ryan et al., 1991). DNA strand breaks, but not other DNA lesions, are capable of inducing p53 accumulation (Nelson and Kastan, 1994; Jayaraman and Prives, 1995; Lee et al., 1995). These observations suggest that excitotoxicity and genotoxic damage share a common pathway for activating neuronal cell death-DNA damage-induced p53 activation. The protection conferred by the absence of either the p53 or Bax gene suggests that these proteins are coupled within a common cell death pathway that is activated in response to some, but not all, death-inducing stimuli.

In contrast to our major results, Bax involvement in programmed cell death that occurs during the development of the nervous system may be independent of p53 activation. For example, the declining viability of neonatal sympathetic neurons after trophic factor deprivation recently has been shown to be dependent on the Bax protein (Deckwerth et al., 1996). However, the absence of p53 does not confer protection on embryonic sensory and sympathetic neurons after the withdrawal of neurotrophins (Davies and Rosenthal, 1994; Sadoul et al., 1996). These results suggest that neurotrophin-deprived peripheral neurons die via a pathway that is dependent on Bax expression but independent of p53. Thus, Bax may function in multiple pathways to regulate neuronal viability during development and in response to injury.

\section{Regulation of Bax expression/activity}

The involvement of Bax in multiple cell death pathways suggests that Bax expression and/or activity is subject to complex patterns of regulation. Our results demonstrated that Bax is expressed constitutively in cultured cortical neurons in the absence of a cytotoxic stimulus and independently of p53. Although camptothecin-induced DNA damage had little effect on Bax expression, excitotoxic injury significantly upregulated the Bax protein. The glutamate-mediated increase in Bax protein was dependent on the presence of the p53 gene, providing additional evidence for p53 activation after excitotoxic injury. Interestingly, increased p53 levels alone, resulting from adenovirus infection, were not sufficient to elevate Bax. Therefore, excitotoxic injury must stimulate other signal transduction pathways that augment Bax transcription, stabilize the Bax protein, or alter its intracellular localization (Hsu et al., 1997). Because Bax-deficient neurons are resistant to both glutamate- and camptothecin-induced cell death, we conclude that Bax must be activated and incorporated into a cell death pathway independently of changes in its expression. Thus, the glutamate-mediated increase in Bax protein observed in the present study may not contribute directly to neuronal cell death but may be secondary to (or associated with) other modifications in the Bax protein.

Bax activity could be integrated into a proapoptotic pathway as a result of distinct changes in the ratio of the Bax protein to cellular antagonists. For example, it is conceivable that p53 indirectly may augment Bax activity by activating additional proapoptotic proteins. Because multiple Bcl-2 family members are expressed in the nervous system, there may be several pathways for regulating Bax that are ultimately contingent on the identity of the injured neuron and the context of the injury.

Results from several different model systems have demonstrated either that Bax is required for apoptosis (McCurrach et al., 1997; Yin et al., 1997) or that an increase in Bax expression precedes apoptosis (Zhan et al., 1994; Bargou et al., 1995; Brady et al., 1996). The results of the present study are consistent with several reports demonstrating that upregulation of the Bax protein occurs in neurons after cerebral ischemia (Krajewski et al., 1995; J. Chen et al., 1996) and after exposure to the amyloid- $\beta$ peptide (Paradis et al., 1996). Trophic factor deprivation-induced cell death in sympathetic and motor neurons was abated in the absence of Bax; however, it was not actually determined whether trophic factor withdrawal elevated Bax expression in wild-type neurons (Deckwerth et al., 1996). In addition, several mutant p53 proteins have been identified that have lost the ability to transactivate some, but not all, cellular p53-responsive promoters (Friedlander et al., 1996; Ludwig et al., 1996). In particular, one mutant p53 protein retained an ability to activate expression of

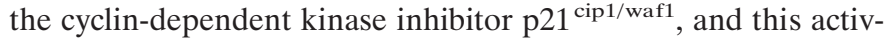
ity correlated with the ability to induce cell cycle arrest. However, this particular p53 mutant was defective in the activation of p53-responsive sequences derived from the Bax and the insulinlike growth factor-binding protein-3 gene promoters. Failure to activate Bax correlated with the impaired apoptotic activity of this mutant p53 gene.

In contrast, several studies have failed to observe detectable increases in Bax expression after p53 activation (Allday et al., 1995; Canman et al., 1995; Knudson et al., 1995; Rowan et al., 1996). These results suggest that p53-induced cell death may require the activation of additional signaling pathways and may be only partially dependent on the presence of Bax. For example, thymocytes derived from Bax-deficient mice exhibit an apparently normal p53-mediated apoptotic response, suggesting that Bax expression is not necessarily coupled to p53-mediated apoptotic activity under all circumstances. The present demonstra- 
tion that high levels of p53 can induce neuronal cell death in the absence of Bax expression is consistent with this possibility.

\section{Mechanisms of Bax-mediated cell death}

Although the present study demonstrated that Bax activity is often involved in p53-mediated cell death, the mechanism by which Bax promotes CNS cell death is not understood. One intriguing possibility is that p53-induced changes in neuronal viability may stem from declining mitochondrial function initiated by alterations in Bax activity. This hypothesis is consistent with the demonstration that mitochondrial dysfunction, including the loss of mitochondrial membrane potential and increased production of reactive oxygen species, plays an obligate role in excitotoxic damage (Ankarcrona et al., 1995; Dugan et al., 1995; Reynolds and Hastings, 1995; Schinder et al., 1996). Disruption of the mitochondrial membrane potential and increased production of reactive oxygen species have been defined as early events in the process of apoptosis (Deckwerth and Johnson, 1993; Vayssiere et al., 1994; Petit et al., 1995; Zamzami et al., 1995; Marchetti et al., 1996) A relationship between Bax activity and alterations in mitochondrial function also would be consistent with the mitochondrial localization of the Bax protein (Zha et al., 1996). Indeed, increased Bax expression has been shown to reduce mitochondrial membrane potential and to activate ICE-like proteases in a lymphoid cell line (J. Xiang et al., 1996) and in sympathetic neurons (Vekrellis et al., 1997). These effects of Bax expression are prevented by $\mathrm{Bcl}-2$ and $\mathrm{Bcl}-\mathrm{x}_{\mathrm{L}}$ (Chinnaiyan et al., 1996; Monney et al., 1996; Shimizu et al., 1996). Interestingly, Bcl-2 recently has been shown to prevent the release of cytochrome $c$ from mitochondria (Kharbanda et al., 1997; Kluck et al., 1997; Yang et al., 1997); cytochrome $c$ promotes caspase activation and apoptotic changes in nuclei in a cell free system (Liu et al., 1996). In addition, recent studies have shown that the crystal structure of $\mathrm{Bcl}-\mathrm{x}_{\mathrm{L}}$ is related to certain bacterial poreforming proteins (Sattler et al., 1997) consistent with the demonstration that the $\mathrm{Bcl}-\mathrm{x}_{\mathrm{L}}, \mathrm{Bcl}-2$, and Bax proteins are capable of forming an ion-conducting channel in synthetic lipid membranes (Antonsson et al., 1997; Minn et al., 1997; Schendel et al., 1997; Schlesinger et al., 1997). Although not yet proven, these channels may play a role in regulating mitochondrial permeability transition. Although the precise relationship between Bax and other Bcl-2 family members remains to be elucidated, it appears that they are tied intimately to the integrity of mitochondrial function.

Recent investigations have demonstrated a perhaps unexpected richness and complexity of cell death pathways. Key elements of the signaling sequence undoubtedly depend not only on the cell type involved but also on the nature of the insult and the developmental stage. Results of the present study demonstrate that, in CNS cortical neurons, excitotoxicity and genotoxic damage induce neuronal cell death by activating a p53-mediated Baxdependent pathway. Thus, suppressing p53-mediated pathways, including alterations in Bax activity, may provide a means for maintaining neuronal viability and metabolic competence after cytopathic insults.

\section{REFERENCES}

Allday MJ, Inman GJ, Crawford DH, Farrell PJ (1995) DNA damage in human B cells can induce apoptosis, proceeding from $\mathrm{G} 1 / \mathrm{S}$ when $\mathrm{p} 53$ is transactivation competent and $\mathrm{G} 2 / \mathrm{M}$ when it is transactivation defective. EMBO J 14:4994-5005.

Altman FP (1976) Tetrazolium salts and formazans. Prog Histochem Cytochem 9:1-56.

Ankarcrona M, Dypbukt JM, Bonfoco E, Zhivotovsky B, Orrenius S,
Lipton SA, Nicotera P (1995) Glutamate-induced neuronal death: a succession of necrosis or apoptosis depending on mitochondrial function. Neuron 15:961-973.

Antonsson B, Conti F, Ciavatta A, Montessuit S, Lewis S, Martinou I, Bernasconi L, Bernard A, Mermod J-J, Mazzei G, Maundrell K, Gambale F, Sadoul R, Martinou J-C (1997) Inhibition of Bax channelforming activity by bcl-2. Science 277:370-372.

Bargou RC, Bommert K, Weinmann P, Daniel PT, Wagener C, Mapara MY, Dorken B (1995) Induction of Bax- $\alpha$ precedes apoptosis in a human B lymphoma cell line: potential role of the bcl-2 gene family in surface IgM-mediated apoptosis. Eur J Immunol 25:770-775.

Barr D, Tubb J, Ferguson D, Scaria A, Lieber A, Wilson C, Perkins J, Kay MA (1995) Strain related variations in adenovirally mediated transgene expression from mouse hepatocytes in vivo: comparisons between immunocompetent and immunodeficient inbred strains. Gene Ther 2:151-155.

Brady HJM, Salomons GS, Bobeldijk RC, Berns AJM (1996) T cells from Bax- $\alpha$ transgenic mice show accelerated apoptosis in response to stimuli but do not show restored DNA damage-induced cell death in the absence of p53. EMBO J 15:1221-1230.

Brewer GJ, Torricelli JR, Evege EK, Price PJ (1993) Optimized survival of hippocampal neurons in B27-supplemented neurobasal, a new serum-free medium combination. J Neurosci Res 35:567-576.

Canman CE, Gilmer TM, Coutts SB, Kastan MB (1995) Growth factor modulation of p53-mediated growth arrest versus apoptosis. Genes Dev 9:600-611.

Chen J, Zhu RL, Nakayama M, Kawaguchi K, Jin K, Stetler RA, Simon RP, Graham SH (1996) Expression of the apoptosis-effector gene, Bax, is up-regulated in vulnerable hippocampal CA1 neurons following global ischemia. J Neurochem 67:64-71.

Chen X, Ko LJ, Jayaraman L, Prives C (1996) p53 levels, functional domains, and DNA damage determine the extent of the apoptotic response of tumor cells. Genes Dev 10:2438-2451.

Chinnaiyan AM, Orth K, O'Rourke K, Duan H, Poirier GG, Dixit VM (1996) Molecular ordering of the cell death pathway. J Biol Chem 271:4573-4576.

Chopp M, Li Y, Zhang ZG, Freytag SO (1992) p53 expression in brain after middle cerebral artery occlusion in the rat. Biochem Biophys Res Commun 182:1201-1207.

Crumrine RC, Thomas AL, Morgan PF (1994) Attenuation of p53 expression protects against focal ischemic damage in transgenic mice. $\mathrm{J}$ Cereb Blood Flow Metab 14:887-891.

Davies AM, Rosenthal A (1994) Neurons from mouse embryos with a null mutation in the tumour suppressor gene p53 undergo normal cell death in the absence of neurotrophins. Neurosci Lett 182:112-114.

Deckwerth TL, Johnson Jr EM (1993) Temporal analysis of events associated with programmed cell death (apoptosis) of sympathetic neurons deprived of nerve growth factor. J Cell Biol 123:1207-1222.

Deckwerth TL, Elliott JL, Knudson CM, Johnson Jr EM, Snider WD, Korsmeyer SJ (1996) Bax is required for neuronal death after trophic factor deprivation and during development. Neuron 17:401-411.

Didier M, Bursztajn S, Adamec E, Passani L, Nixon RA, Coyle JT, Wei JY, Berman SA (1996) DNA strand breaks induced by sustained glutamate excitotoxicity in primary neuronal cultures. J Neurosci 16:2238-2250.

Donehower LA, Harvey M, Slagle BL, McArthur MJ, Montgomery Jr CA, Butel JS, Bradley A (1992) Mice deficient for p53 are developmentally normal but susceptible to spontaneous tumours. Nature 356:215-221.

Dugan LL, Sensi SL, Canzoniero LMT, Handran SD, Rothman SM, Lin TS, Goldberg MP, Choi DW (1995) Mitochondrial production of reactive oxygen species in cortical neurons following exposure to NMDA. J Neurosci 15:6377-6388.

Eizenberg O, Faber-Elman A, Gottlieb E, Oren M, Rotter V, Schwartz M (1996) p53 plays a regulatory role in differentiation and apoptosis of central nervous system-associated cells. Mol Cell Biol 16:5178-5185.

Enokido Y, Araki T, Aizawa S, Hatanaka H (1996a) p53 involves cytosine arabinoside-induced apoptosis in cultured cerebellar granule neurons. Neurosci Lett 203:1-4.

Enokido Y, Araki T, Tanaka K, Aizawa S, Hatanaka H (1996b) Involvement of p53 in DNA strand break-induced apoptosis in postmitotic CNS neurons. Eur J Neurosci 8:1812-1821.

Farmer G, Bargonetti J, Zhu H, Friedman P, Prywes R, Prives C (1992) Wild-type p53 activates transcription in vitro. Nature 358:83-86.

Finiels F, Robert JJ, Samolyk ML, Privat A, Mallet J, Revah F (1995) Induction of neuronal apoptosis by excitotoxins associated with long- 
lasting increase of 12-O-tetradecanoylphorbol 13-acetate-responsive element-binding activity. J Neurochem 65:1027-1034.

Friedlander P, Haupt Y, Prives C, Oren M (1996) A mutant p53 that discriminates between p53-responsive genes cannot induce apoptosis. Mol Cell Biol 16:4961-4971.

Giordano S, Sherman L, Lyman W, Morrison RS (1992) Multiple molecular weight forms of basic fibroblast growth factor are developmentally regulated in the central nervous system. Dev Biol 152:293-303.

Hsu Y, Wolter KG, Youle RJ (1997) Cytosol-to-membrane redistribution of Bax and Bcl- $\mathrm{x}_{\mathrm{L}}$ during apoptosis. Proc Natl Acad Sci USA 94:3668-3672.

Jayaraman L, Prives C (1995) Activation of p53 sequence-specific DNA binding by short single strands of DNA requires the p53 C-terminus. Cell 81:1021-1029.

Jordan J, Galindo MF, Prehn JHM, Weichselbaum RR, Beckett M, Ghadge GD, Roos RP, Leiden JM, Miller RJ (1997) p53 expression induces apoptosis in hippocampal pyramidal neuron cultures. J Neurosci 17:1397-1405.

Kanegae Y, Lee G, Sato Y, Tanaka M, Nakai M, Sakaki T, Sugano S, Saito I (1995) Efficient gene activation in mammalian cells by using recombinant adenovirus expressing site-specific Cre recombinase. $\mathrm{Nu}-$ cleic Acids Res 23:3816-3821.

Kern SE, Kinzler KW, Bruskin A, Jarosz D, Friedman P, Prives C, Vogelstein B (1991) Identification of p53 as a sequence-specific DNAbinding protein. Science 252:1708-1711.

Kharbanda S, Pandey P, Schofield L, Israels S, Roncinske R, Yoshida K, Bharti A, Yuan Z-M, Saxena S, Weichselbaum R, Nalin C, Kufe D (1997) Role for Bcl- $\mathrm{x}_{\mathrm{L}}$ as an inhibitor or cytosolic cytochrome $c$ accumulation in DNA damage-induced apoptosis. Proc Natl Acad Sci USA 94:6939-6942.

Kluck RM, Bossy-Wetzel E, Green DR, Newmeyer DD (1997) The release of cytochrome $c$ from mitochondria: a primary site for Bcl-2 regulation of apoptosis. Science 275:1132-1136.

Knudson CM, Korsmeyer SJ (1997) Bcl-2 and Bax function independently to regulate cell death. Nat Genet 16:358-363.

Knudson CM, Tung KSK, Tourtellotte WG, Brown GAJ, Korsmeyer SJ (1995) Bax-deficient mice with lymphoid hyperplasia and male germ cell death. Science 270:96-98.

Krajewski S, Mai JK, Krajewska M, Sikorska M, Mossakowski MJ, Reed JC (1995) Upregulation of Bax protein levels in neurons following cerebral ischemia. J Neurosci 15:6364-6376.

Kuida K, Zheng TS, Na S, Kuan C, Yang D, Karasuyama H, Rakic P, Flavell RA (1996) Decreased apoptosis in the brain and premature lethality in CPP32-deficient mice. Nature 384:368-372.

Lee S, Elenbaas B, Levine A, Griffith J (1995) p53 and its 14 kDa C-terminal domain recognize primary DNA damage in the form of insertion/deletion mismatches. Cell 81:1013-1020.

Li Y, Chopp M, Zhang ZG, Zaloga C, Niewenhuis L, Gautam S. p53-immunoreactive protein and p53 mRNA expression after transient middle cerebral artery occlusion in rats. Stroke 1994;25:849-855.

Liu XS, Kim CN, Yang J, Jemmerson R, Wang XD (1996) Induction of apoptotic program in cell-free extracts: requirement for dATP and cytochrome $c$. Cell 86:147-157.

Ludwig RL, Bates S, Vousden KH (1996) Differential activation of target cellular promoters by p53 mutants with impaired apoptotic function. Mol Cell Biol 16:4952-4960.

Marchetti P, Castedo M, Susin SA, Zamzami N, Hirsch T, Macho A, Haeffner A, Hirsch F, Geuskens M, Kroemer G (1996) Mitochondrial permeability transition is a central coordinating event of apoptosis. J Exp Med 184:1155-1160.

McCurrach ME, Connor TMF, Knudson CM, Korsmeyer SJ (1997) Bax deficiency promotes drug resistance and oncogenic transformation by attenuating p53-dependent apoptosis. Proc Natl Acad Sci USA 94:2345-2349.

Minn AJ, Velez P, Schendel SL, Liang H, Muchmore SW, Fesik SW, Fill M, Thompson CB (1997) Bcl- $\mathrm{x}_{\mathrm{L}}$ forms an ion channel in synthetic lipid membranes. Nature 385:353-357.

Miyashita T, Reed JC (1995) Tumor suppressor p53 is a direct transcriptional activator of the human Bax gene. Cell 80:293-299.

Miyashita T, Krajewski S, Krajewska M, Wang HG, Lin HK, Liebermann DA, Hoffman B, Reed JC (1994) Tumor suppressor p53 is a regulator of bcl-2 and Bax gene expression in vitro and in vivo. Oncogene 9:1799-1805.

Monney L, Otter I, Olivier R, Ravn U, Mirzasaleh H, Fellay I, Poirier GG, Borner C (1996) Bcl-2 overexpression blocks activation of the death protease CPP32/yama/apopain. Biochem Biophys Res Commun 221:340-345.

Morrison RS, Wenzel HJ, Kinoshita Y, Robbins CA, Donehower LA, Schwartzkroin PA (1996) Loss of the p53 tumor suppressor gene protects neurons from kainate-induced cell death. J Neurosci 16:1337-1345.

Motoyama N, Wang F, Roth KA, Sawa H, Nakayama K, Nakayama K, Negishi I, Senju S, Zhang Q, Fujii S, Loh DY (1995) Massive cell death of immature hematopoietic cells and neurons in Bcl-x-deficient mice. Science 267:1506-1510.

Nelson WG, Kastan MB (1994) DNA strand breaks: the DNA template alterations that trigger p53-dependent DNA damage response pathways. Mol Cell Biol 14:1815-1823.

Nicholson DW (1996) ICE/CED3-like proteases as therapeutic targets for the control of inappropriate apoptosis. Nat Biotechnol 14:297-301.

Oltvai ZN, Korsmeyer SJ (1994) Checkpoints of dueling dimers foil death wishes. Cell 79:189-192.

Oltvai ZN, Milliman CL, Korsmeyer SJ (1993) Bcl-2 heterodimerizes in vivo with a conserved homolog, Bax, that accelerates programmed cell death. Cell 74:609-619.

Paradis E, Douillard H, Koutroumanis M, Goodyear C, LeBlanc A (1996) Amyloid- $\beta$ peptide of Alzheimer's disease downregulates Bcl-2 and upregulates Bax expression in human neurons. J Neurosci 16:7533-7539.

Petit PX, LeCoeur H, Zorn E, Dauguet C, Mignotte B, Gougeon ML (1995) Alterations of mitochondrial structure and function are early events of dexamethasone-induced thymocyte apoptosis. J Cell Biol 130:157-167.

Portera-Cailliau C, Hedreen JC, Price DL, Koliatsos VE (1995) Evidence for apoptotic cell death in Huntington disease and excitotoxic animal models. J Neurosci 15:3775-3787.

Raff MC, Barres BA, Burne JF, Coles HS, Ishizaki Y, Jacobson MD (1993) Programmed cell death and the control of cell survival: lessons from the nervous system. Science 262:695-700.

Reed JC (1997) Double identity for proteins of the Bcl-2 family. Nature 387:773-776.

Reynolds IJ, Hastings TG (1995) Glutamate induces the production of reactive oxygen species in cultured forebrain neurons following NMDA receptor activation. J Neurosci 15:3318-3327.

Rowan S, Ludwig RL, Haupt Y, Bates S, Lu X, Oren M, Vousden KH (1996) Specific loss of apoptotic but not cell cycle arrest function in a human tumour-derived p53 mutant. EMBO J 15:827-838.

Ryan AJ, Squires S, Strutt HL, Johnson RT (1991) Camptothecin cytotoxicity in mammalian cells is associated with the induction of persistent double strand breaks in the replicating DNA. Nucleic Acids Res 19:3295-3300.

Sadoul R, Quiquerez AL, Martinou I, Fernandez PA, Martinou JC (1996) p53 protein in sympathetic neurons: cytoplasmic localization and no apparent function in apoptosis. J Neurosci Res 43:594-601.

Sakhi S, Bruce A, Sun N, Tocco G, Baudry M, Schreiber SS (1994) p53 induction is associated with neuronal damage in the central nervous system. Proc Natl Acad Sci USA 91:7525-7529.

Sakhi S, Gilmore W, Tran ND, Schreiber SS (1996) p53-deficient mice are protected against adrenalectomy-induced apoptosis. NeuroReport 8:233-235.

Sattler M, Liang H, Nettesheim D, Meadows RP, Harlan JE, Eberstadt M, Yoon HS, Shuker SB, Chang BS, Minn AJ, Thompson CB, Fesik SW (1997) Structure of Bcl- $\mathrm{x}_{\mathrm{L}}-\mathrm{Bak}$ peptide complex: recognition between regulators of apoptosis. Science 275:983-986.

Schendel SL, Xie ZH, Montal MO, Matsuyama S, Montal M, Reed JC (1997) Channel formation by antiapoptotic protein Bcl-2. Proc Natl Acad Sci USA 94:5113-5118.

Schinder AF, Olson EC, Spitzer NC, Montal M (1996) Mitochondrial dysfunction is a primary event in glutamate neurotoxicity. J Neurosci 16:6125-6133.

Schlesinger PH, Gross A, Yin X-M, Yamamoto K, Saito M, Waksman G, Korsmeyer SJ (1997) Comparison of the ion channel characteristics of pro-apoptotic Bax and anti-apoptotic Bcl-2. Proc Natl Acad Sci USA 94:11357-11362.

Shimizu S, Eguchi Y, Kamiike W, Waguri S, Uchiyama Y, Matsuda H, Tsujimoto Y (1996) Bcl-2 blocks loss of mitochondrial membrane potential while ICE inhibitors act at a different step during inhibition of death induced by respiratory chain inhibitors. Oncogene 13:21-29.

Slater TF, Sawyer B, Sträuli U (1963) Studies on succinate-tetrazolium reductase systems. Biochim Biophys Acta 77:383-393.

Smale G, Nichols NR, Brady DR, Finch CE, Horton WE (1995) Evi- 
dence for apoptotic cell death in Alzheimer's disease. Exp Neurol 133:225-230.

Su JH, Anderson AJ, Cummings BJ, Cotman CW (1994) Immunohistochemical evidence for apoptosis in Alzheimer's disease. NeuroReport 5:2529-2533.

Thomas LB, Gates DJ, Richfield EK, O'Brien TF, Schweitzer JB, Steindler DA (1995) DNA end labeling (TUNEL) in Huntington's disease and other neuropathological conditions. Exp Neurol 133:265-272.

Thompson CB (1995) Apoptosis in the pathogenesis and treatment of disease. Science 267:1456-1462.

Timme T, Thompson TC (1994) Rapid allelotype analysis of p53 knockout mice. Biotechnology 17:461-463.

Trimmer PA, Smith TS, Jung AB, Bennett JP (1996) Dopamine neurons from transgenic mice with a knockout of the p53 gene resist MPTP neurotoxicity. Neurodegeneration 5:233-239.

Troost D, Aten J, Morsink F, de-Jong JM (1995) Apoptosis in amyotrophic lateral sclerosis is not restricted to motor neurons. Bcl-2 expression is increased in unaffected post-central gyrus. Neuropathol Appl Neurobiol 21:498-504.

Vayssiere JL, Petit PX, Risler Y, Mignotte B (1994) Commitment to apoptosis is associated with changes in mitochondrial biogenesis and activity in cell lines conditionally immortalized with simian virus 40 . Proc Natl Acad Sci USA 91:11752-11756.

Vekrellis K, McCarthy MJ, Watson A, Whitfield J, Rubin LL, Ham J (1997) Bax promotes neuronal cell death and is downregulated during the development of the nervous system. Development 124:1239-1249.

Wood KA, Youle RJ (1995) The role of free radicals and p53 in neuron apoptosis in vivo. J Neurosci 15:5851-5857.

Xiang H, Hochman DW, Saya H, Fujiwara T, Schwartzkroin PA, Morrison RS (1996) Evidence for p53-mediated modulation of neuronal viability. J Neurosci 16:6753-6765.
Xiang JG, Chao DT, Korsmeyer SJ (1996) Bax-induced cell death may not require interleukin $1 \beta$-converting enzyme-like proteases. Proc Natl Acad Sci USA 9:14559-14563.

Yang J, Liu XS, Bhalla K, Kim CN, Ibrado AM, Cai JY, Peng TI, Jones DP, Wang X (1997) Prevention of apoptosis by Bcl-2: release of cytochrome $c$ from mitochondria blocked. Science 275:1129-1132.

Yin C, Knudson CM, Korsmeyer SJ, Van Dyke T (1997) Bax suppresses tumorigenesis and stimulates apoptosis in vivo. Nature 385:637-640.

Yoshiyama Y, Yamada T, Asanuma K, Asahi T (1994) Apoptosis related antigen, $\mathrm{Le}(\mathrm{Y})$, and nick-end labeling are positive in spinal motor neurons in amyotrophic lateral sclerosis. Acta Neuropathol (Berl) 88:207-211.

Zambetti GP, Bargonetti J, Walker K, Prives C, Levine AJ (1992) Wild-type p53 mediates positive regulation of gene expression through a specific DNA sequence element. Genes Dev 6:1143-1152.

Zamzami N, Marchetti P, Castedo M, Zanin C, Vayssiere JL, Petit PX, Kroemer G (1995) Reduction in mitochondrial potential constitutes an early irreversible step of programmed lymphocyte death in vivo. J Exp Med 181:1661-1672.

Zha H, Fisk HA, Yaffe MP, Mahajan N, Herman B, Reed JC (1996) Structure-function comparisons of the proapoptotic protein Bax in yeast and mammalian cells. Mol Cell Biol 16:6494-6508.

Zhan Q, Fan S, Bae I, Guillouf C, Liebermann DA, O'Connor PM, Fornace Jr AJ (1994) Induction of Bax by genotoxic stress in human cells correlates with normal p53 status and apoptosis. Oncogene 9:3743-3751.

Zhang WW, Fang X, Branch CD, Mazur W, French BA, Roth JA (1993) Generation and identification of recombinant adenovirus by liposome-mediated transfection and PCR analysis. Biotechniques $15: 868-872$. 